\title{
Artikel
}

\section{Pleidooi voor de terugdringing van de korte gevangenisstraf}

Prof. mr. J.A.A.C. (Jacques) Claessen*

NTS 2021/40

\section{Inleiding: de korte gevangenisstraf als problematische sanctie}

In 2009 concludeerde een antal onderzoekers 'dat detentie geen dan wel een criminogeen effect heeft op herhaald crimineel gedrag. ${ }^{1}{ }^{\mathrm{Zij}}$ waarschuwden rechters dat zij zich geen illusies moeten maken over het realiseren van speciale preventie door middel van de gevangenisstraf, afgezien van een insluitingseffect: 'Met gevangenisstraf voorkomen zij waarschijnlijk geen recidive en resocialisatie wordt waarschijnlijk ook niet gerealiseerd. ${ }^{2}$ Kijkend naar de recidivecijfers van toen en nu moeten we vaststellen dat de hiervoor aangehaalde uitspraken niets aan geldigheid hebben verloren. De recidivecijfers na detentie zijn nog steeds hoog: ca. $47 \%$ van

* $\quad$ Prof. mr. J.A.A.C. Claessen is bijzonder hoogleraar herstelrecht en universitair hoofddocent strafrecht aan de Faculteit der Rechtsgeleerdheid van de Universiteit Maastricht. Daarnaast is hij rechter-plaatsvervanger bij de rechtbank Limburg. De auteur wil graag drs. Gert Jan Slump bedanken voor diens commentaar op een eerdere versie van dit artikel. Claessen en Slump zijn programmaleiders binnen het 3-jarige project Changing Justice Gears dat o.a. ziet op doelbewuste straftoemeting en de ontwikkeling van alternatieven voor de korte gevangenisstraf.

1. A. Dirkzwager, W. Lamet, P. Nieuwbeerta, A. Blokland \& P. van der Laan, 'Na detentie: de gevolgen van rechtspraak', Rechtstreeks 2009 (1), p. 24.

2. Dirkzwager e.a. 2009 , p. 28. de ex-gedetineerden gaat opnieuw de fout in binnen twee jaar na invrijheidstelling; in werkelijkheid ligt dit percentage nog hoger, omdat lang niet alle criminaliteit wordt ontdekt en opgehelderd. ${ }^{3}$ Ondanks tegenvallende recidivecijfers is de kans om als dader een gevangenisstraf opgelegd te krijgen in Nederland relatief groot. ${ }^{4}$

Natuurlijk kijkt de rechter in het kader van zijn sanctioneringsbeslissing niet alleen naar resocialisatie en recidivereductie als doel, maar ook naar vergelding. Zeker bij zwaardere delicten zal vergelding een zodanig gewicht in de schaal leggen dat hij - gegeven het huidige sanctiearsenaal - moeilijk voor een andere sanctie kan kiezen dan een (deels) onvoorwaardelijke gevangenisstraf; ik laat maatregelen als tbs hier buiten beschouwing. Echter, maar liefst $73 \%$ van alle gedetineerden zit korter dan drie maanden vast. ${ }^{5}$ Als we daarbij de gedetineerden die korter dan zes maanden gevangen zitten optellen, dan komen we uit op ruim $80 \%$. Met andere woorden: de kans op een korte gevangenisstraf is in Nederland groot. Het betreft over het algemeen daders die zijn veroordeeld wegens lichtere strafbare feiten. Dat kunnen daders zijn die direct een gevangenisstraf opgelegd hebben gekregen, maar ook daders die in de cel belanden omdat zij hun geldboete niet betalen of hun taakstraf niet volbrengen (zie art. 24c Sr resp. art. 22d $\mathrm{Sr}$ inzake vervangende hechtenis). Voorts betreft het daders die een gevangenisstraf opgelegd hebben gekregen gelijk aan hun voorarrest en die dus feitelijk hun

3. Infographic Recidive in beeld 2019, www.wodc.nl

4. F. van Tulder \& R. Kroon, 'Uitermate effectief?', Nederlands Juristenblad 2012, 1861; F. van Tulder, 'Is de rechter zwaarder gaan straffen? Twee decennia in beeld', Tijdschrift voor rechtspraak en straftoemeting 2019 (1/2), p. 73-82.

5. Infographic Gevangeniswezen 2020, www.dji.nl. 
straf hebben uitgezeten tijdens hun preventieve hechtenis (art. $27 \mathrm{Sr}$ ).

De LOVS-oriëntatiepunten tonen dat relatief veel delicten, vooral heel wat gewelds-, vermogens- en verkeersdelicten, in aanmerking komen voor een gevangenisstraf korter dan zes maanden. ${ }^{6}$ De vraag is of bij dergelijke delicten in beginsel niet zou kunnen of wellicht zou moeten worden gekozen voor de oplegging van een andere straf dan een gevangenisstraf. Terwijl de rechter in 1886, toen het huidige Wetboek van Strafrecht in werking trad, uitsluitend kon kiezen tussen een geldboete of vrijheidsbeneming (principale hechtenis bij overtredingen en gevangenisstraf bij misdrijven), is zijn keuzeruimte inmiddels groter geworden, onder meer doordat hij sinds 2001 kan kiezen voor de oplegging van een taakstraf (art. 9 lid $2 \mathrm{Sr}$ ). Zou de rechter niet vaker dan nu het geval is, gebruik kunnen en wellicht moeten maken van die taakstraf? En zou thuisdetentie niet eveneens een goed alternatief zijn voor de korte gevangenisstraf tot zes maanden?

Waarom ik de cesuur bij zes maanden leg? Omdat enkel gedetineerden die minimaal voor zes maanden in de cel belanden, in aanmerking komen voor een penitentiair programma (art. 4 Pbw) dan wel voorwaardelijke invrijheidstelling (vanaf één jaar gevangenisstraf; art. 6:2:10 $\mathrm{Sv})$. Gedetineerden die korter dan zes maanden moeten zitten, zijn vrijwel uitsluitend bezig met 'doing time' een weinig zinvolle 'bezigheid' die eerder een negatieve dan een positieve uitwerking op hen heeft. Van de gevangenisstraf wordt wel gezegd dat zij een dure manier is om mensen slechter te maken, al was het maar door het ontstaan van detentieschade. Misschien geldt deze uitspraak wel het meest voor de korte gevangenisstraf, in het kader waarvan vrijwel niets gebeurt wat betreft resocialisatie - en in het verlengde daarvan recidivereductie. Als dat zo is, moeten we dan niet op zoek naar goede alternatieven? Alternatieven die tegemoetkomen aan vergeldingsbehoeften, maar die wel een bijdrage leveren aan resocialisatie en recidivereductie en die niet met detentieschade gepaard gaan. De vraag stellen is haar beantwoorden.

\section{Taakstraf en thuisdetentie als alternatieven}

\subsection{De effectiviteit van de alternatieven in} termen van recidivereductie

Die alternatieven zijn er immers. Zo blijkt uit onderzoek, waarin gematcht is vergeleken, ${ }^{7}$ dat daders

6. Oriëntatiepunten voor straftoemeting en LOVS-afspraken, www.rechtspraak.nl.

7. Een gematchte vergelijking houdt - simpel gezegd - in dat dadergroepen zo veel mogelijk zijn gelijkgesteld op factoren die relevant kunnen zijn voor recidive (denk aan geslacht, leeftijd, nationaliteit, delict, delictsgeschiedenis), zodat 'het enige verschil' het verschil in sanctionering is: de ene dadergroep krijgt een korte gevangenisstraf, de andere dadergroep een taakstraf of elektronische detentie. die een taakstraf opgelegd krijgen, significant minder recidiveren dan daders die voor korte tijd de gevangenis in moeten: ' $\mathrm{Na}$ werkstraffen recidiveerden daders minder, zowel op de korte als op de lange termijn - gemiddeld 50 procent minder veroordelingen over een periode van acht jaar. Dit wordt gevonden voor zowel mannen als vrouwen en op verschillende leeftijden.' ${ }^{8}$ Hetzelfde geldt voor daders die elektronische detentie oftewel thuisdetentie met een enkelband opgelegd krijgen. Onderzoek waarin de recidive na elektronische thuisdetentie gematcht is vergeleken met de recidive na reguliere detentie, laat de volgende resultaten zien: ' $\mathrm{Na}$ een jaar is 18 procent van de regulier gedetineerde groep opnieuw gedetineerd geraakt tegenover vijf procent van de elektronisch-toezichtgroep. Het verschil tussen beide groepen blijft ook op langere termijn bestaan, na drie en vijf jaar is respectievelijk 38 procent en 46 procent van de regulier gedetineerde groep opnieuw gedetineerd, terwijl dit voor de elektronisch-toezichtgroep respectievelijk 17 procent en 24 procent bedraagt.' 9

Beide onderzoeken, die laten zien dat taakstraffen respectievelijk thuisdetentie effectiever zijn in termen van recidivereductie dan korte gevangenisstraffen, zijn in lijn met een meta-analyse van Nederlands onderzoek naar recidive-effecten van strafrechtelijke interventies. De onderzoekers die deze meta-analyse hebben uitgevoerd, concluderen 'dat projecten gestoeld op het principe van "resocialisatie" in de loop der jaren betere resultaten te zien hebben gegeven dan sancties gericht op "afschrikking"". ${ }^{10}$ En ja, taakstraffen en thuisdetentie focussen meer op resocialisatie en minder op afschrikking en vergelding dan korte gevangenisstraffen.

Bovengenoemde onderzoeken plaatsen expliciet vraagtekens bij de afschrikkingstheorie die ervan uitgaat dat de meest strenge sanctie (waarbij geldt dat de gevangenisstraf zwaarder wordt geacht dan de taakstraf of thuisdetentie) de meest afschrikwekkende sanctie is en dientengevolge het meest effectief qua recidivereductie zou zijn. De Britse criminoloog Cornwell makt korte metten met deze theorie en stelt op basis van de praktijk in lijn met Nederlands onderzoek: 'From (...) evidence-based research as is available, it becomes clear that increasing sanctions severity and the use of short term imprisonment for deterrent purposes significantly fails to reduce recidivism, and probably encourages it. ${ }^{11}$

\subsection{Taakstrafverbod als hinderpaal}

Zoals gezegd, de taakstraf is sinds 2001 een zelfstandige hoofdstraf in ons land. Echter, (1) bij misdrijven waarop

8. H. Wermink, A. Blokland, P. Nieuwbeerta \& N. Tollenaar, 'Recidive na werkstraffen en na gevangenisstraffen. Een gematchte vergelijking', Tijdschrift voor Criminologie 2009 (3), p. 211-227, p. 224.

9. A. Blokland, H. Wermink, L. Robert \& E. Maes, 'Wederopsluiting na elektronische detentie en reguliere detentie in België', Tijdschrift voor Criminologie 2015 (1), p. 31-58, p. 51.

10. B. Wartna, D. Alberda \& S. Verweij, 'Een meta-analyse van Nederlands recidiveonderzoek naar de effecten van strafrechtelijke interventies', Tijdschrift voor Criminologie, 2013 (1), p. 3-23, p. 19.

11. D.J. Cornwell, Criminal Deterrence Theory. The History, Myths \& Realities, Den Haag: Eleven International Publishing 2018, p. 153. 
naar de wet een gevangenisstraf van zes jaar of meer is gesteld en die een ernstige inbreuk op de lichamelijke integriteit van het slachtoffer tot gevolg hebben en (2) wanneer voor een soortgelijk delict reeds eerder aan de verdachte een taksstraf is opgelegd, is het de rechter sinds 2012 verboden om een taakstraf op te leggen; hij moet dan kiezen voor een onvoorwaardelijke gevangenisstraf, die wel mag worden gecombineerd met een taakstraf (art. 22b Sr); bij een dergelijke combinatie kan het onvoorwaardelijke deel van de gevangenisstraf overigens maximaal zes maanden zijn (art. 9 lid $4 \mathrm{Sr}$ ).

Duidelijk is dat de rechter niet blij is met het taakstrafverbod. ${ }^{12}$ In bepaalde gevallen, waarin dit volgens de wet niet meer is toegestaan, blijkt hij namelijk wel te willen kiezen voor de oplegging van een taakstraf, gezien de persoon van de verdachte en/of de omstandigheden van het geval. Op die manier kan de rechter willen voorkomen dat de verdachte zijn woning, baan en/of sociale netwerk kwijtraakt of dat hij negatief wordt beïnvloed door de detentie en de gedetineerden. De rechter blijkt in de praktijk het taakstrafverbod dan ook regelmatig te omzeilen, door te doen alsof artikel 22b Sr niet bestaat, door een korte onvoorwaardelijke gevangenisstraf op te leggen (vaak gelijk aan het voorarrest, indien daarvan sprake is geweest) of door een geldboete op te leggen (een geldboeteverbod bestaat immers niet). In de Valkenburgse zedenzaak heeft de Hoge Raad zijn fiat verleend aan de omzeiling van artikel $22 \mathrm{~b} \mathrm{Sr}$ door de oplegging van een zeer korte onvoorwaardelijke gevangenisstraf, omdat de wetgever nergens met zoveel woorden zou hebben aangegeven dat het om een substantiële vrijheidsbeneming moet gaan. ${ }^{13}$

Hoewel het ook een principiële kwestie is (het lijkt erop dat de Nederlandse rechter nu eenmaal het liefst volledige straftoemetingsvrijheid heeft en niet wordt 'beknot' door bijzondere strafminima), lijkt deze omzeiling tevens voort te komen uit het bewustzijn bij de rechter dat de gevangenisstraf diep in het leven van mensen ingrijpt en dus ultimum remedium dient te zijn. Een ruimere toepassing van de taakstraf als alternatief voor de korte gevangenisstraf is erbij gebaat wanneer het taakstrafverbod zou worden afgeschaft. Helaas moeten we constateren dat de wetgever daar vooralsnog anders over denkt, nu de Tweede Kamer inmiddels het wetsvoorstel inzake de uitbreiding van het taakstrafverbod wat betreft geweld tegen hulpverleners - met een kleine meerderheid - heeft aangenomen. ${ }^{14}$ Opmerkelijk is dat verscheidene adviesorganen van de wetgever zeer kritisch staan tegenover dit wetsvoorstel, waaronder de Raad van State en de Raad voor de Strafrechtstoepassing en Jeugdbescherming.

\footnotetext{
12. F.S. Bakker, 'Het taakstrafverbod van artikel $22 \mathrm{~b}$ Sr: is de rechter ongehoorzaam?', Delikt \& Delinkwent 2016 (5), p. 289-305.

13. HR 20 februari 2018, ECLI:NL:HR:2018:202.

14. Kamerstukken II 2019/20, 35528.
}

2.3 Gebrek aan wettelijke basis als hinderpaal Anders dan de taakstraf is elektronische detentie nog geen zelfstandige hoofdstraf in Nederland. Hoewel er enkele pilots hebben plaatsgevonden met elektronische detentie in 1995 en 2003 en het er in 2013 heel even naar uitzag dat de mogelijkheid van elektronische detentie landelijk zou worden ingevoerd, is het daarna stil geworden rond dit alternatief voor de korte gevangenisstraf. In 2013 kwam toenmalig Staatssecretaris van Veiligheid \& Justitie Teeven met een conceptwetsvoorstel dat de uitvoerende macht (Dienst Justitiële Inrichtingen) de bevoegdheid gaf om gevangenisstraffen tot zes maanden om te zetten in thuisdetentie, tenzij de rechter deze mogelijkheid in een concreet geval expliciet had geblokkeerd. ${ }^{15} \mathrm{Al}$ snel verdween het idee in de la - wegens commotie in de media. De reden volgens Teeven was dat de adviesorganen afwijzend stonden tegenover zijn voorstel. De meeste adviesorganen waren echter niet tegen elektronische detentie an sich, maar enkel tegen de bevoegdheid van DJI om over omzetting van gevangenisstraf naar thuisdetentie te beslissen; deze bevoegdheid diende volgens hen in handen te liggen van de rechter. Het conceptwetsvoorstel had vrij eenvoudig kunnen worden aangepast door elektronische detentie als zelfstandige hoofdstraf in te voeren in artikel $9 \mathrm{Sr}-$ qua zwaarte tussen de taakstraf en de gevangenisstraf in. Dat is niet gebeurd. Anno 2021 is thuisdetentie nog steeds geen mogelijk alternatief voor de korte gevangenisstraf en daarmee vormt Nederland een uitzondering op de Europese regel. ${ }^{16}$

Om één Europees land te noemen dat wel elektronische detentie kent: Zweden. Daar bestaat sinds 1997 de landelijke mogelijkheid van thuisdetentie als alternatief voor een gevangenisstraf tot drie maanden en sinds 2005 voor een gevangenisstraf tot zes maanden. ${ }^{17}$ Overigens zij opgemerkt dat in Zweden de reclassering bepaalt of thuisdetentie in een concreet geval mogelijk is - en dus niet de rechter. Belangrijke voorwaarden voor toepassing zijn: de veroordeelde dient zelf een verzoek in tot deelname, er is sprake van deugdelijke huisvesting en huisgenoten stemmen vrijwillig in met de thuisdetentie van hun huisgenoot. Verder dient de veroordeelde te beschikken over een nuttige dagbesteding, dient hij zo nodig deel te nemen aan hulpprogramma's gericht op resocialisatie en geldt voor hem een alcohol- en drugsverbod. Via GPS-controle (enkelband), onaangekondigde huisbezoeken en telefooncontact wordt toezicht gehouden. Overtreedt de veroordeelde een van de voorwaarden, dan loopt hij het risico alsnog naar de gevange-

15. J. Claessen, 'Wat we van onze zuiderburen kunnen leren: elektronische detentie in het strafrecht', Nieuwsbrief Strafrecht 2015 (8), p. 588-590; Kamerstukken I/ 2013/14, 33745.

16. M.H. Nagtegaal, Elektronische detentie als alternatief voor gevangenisstraf: Een quickscan naar Europese ervaringen, WODC, Den Haag 2013.

17. R. Kristoffersen, 'Correctional Statistics of Denmark, Finland, Iceland, Norway and Sweden 2008-2012', Kriminalomsorgen 2013; M. Nellis \& J. Bungerfeldt, 'Electronic monitoring and probation in Sweden and England and Wales: Comparative policy developments', Probation Journal 2013. 
nis te moeten. Vrijwel alle voorwaarden die gelden voor de Zweedse variant van thuisdetentie waren terug te vinden in het conceptwetsvoorstel van Teeven. Daarnaast waren hierin bepaalde groepen daders uitgesloten, onder wie daders met een ernstige stoornis of verslaving. Ik zou ervoor willen pleiten om het conceptwetsvoorstel uit 2013 uit de la te halen en bij de tijd te brengen - met oog voor de huidige (herstelrechtelijke) inzichten en behoeften (zie hieronder).

\section{De alternatieven bezien vanuit een maximalistisch herstelrechtelijk perspectief}

\subsection{Maximalistisch herstelrecht}

Herstelrecht kan worden gedefinieerd als: 'Het handhaven van het recht door het herstellen van de schade die is veroorzaakt door een (vermoedelijk) strafbaar feit, hetgeen het beste kan worden bereikt door vormen van samenwerking tussen (alle) bij het conflict betrokken partijen/personen. ${ }^{18}$ Daarbij wordt in de regel primair of vrijwel exclusief gedacht aan herstelrechtvoorzieningen als bemiddeling, mediation en de herstelconferentie; dat zijn vrijwillige overlegprocessen tussen de conflictpartijen (dader, slachtoffer en/of de gemeenschap) die idealiter uitmonden in consensueel herstel. Echter, indien dergelijke processen niet mogelijk blijken nadat er een misdaad is gepleegd (bijvoorbeeld omdat een conflictpartij niet wil deelnemen), dan blijft in een zogeheten maximalistisch herstelrecht herstel in het kader van de sanctionering het primaire doel; het is dan aan de officier van justitie dan wel de rechter om zo herstelgericht mogelijk te sanctioneren zodat in feite sprake is van opgelegd herstel. ${ }^{19}$ De founding father van dit maximalistische herstelrecht, Lode Walgrave, schrijft: 'Een beperking tot vrijwillige overlegprocessen sluit herstelrecht op in de marges van het systeem (...), een aanhangsel bij het mainstream strafrecht' en 'De voorrang voor overlegprocessen is ingegeven door het feit dat ze meestal een hoger niveau van herstel tot stand kunnen brengen. Maar indien dat niet mogelijk is, dan moeten ook dwingende verplichtingen met het oog op reparatie worden overwogen. ${ }^{\text {,20 }}$

Of opgelegd herstel als straf moet worden gezien, daarover verschillen de visies. Zelf vind ik dat dwang alleen een sanctie nog niet tot straf makt; daarvoor is intentionele leedtoevoeging nodig ('dubbele dwang' oftewel

18. J. Claessen, J. Blad, G.J. Slump e.a., Voorstel van Wet strekkende tot de invoering van herstelrechtvoorzieningen in het Wetboek van Strafvordering, inclusief Memorie van Toelichting, Nijmegen: Wolf Legal Publishers 2018; J. Claessen \& K. Roelofs, 'Herstelrecht(voorzieningen) en mediation in strafzaken', in: J. Boksem e.a. (red.), Handboek Strafzaken, Alphen aan den Rijn: Wolters Kluwer 2020, hoofdstuk 49.

19. J. Claessen, 'Pleidooi voor en uitwerking van een maximalistisch herstelrecht', Tijdschrift voor Herstelrecht 2020 (4), p. 18-30.

20. L. Walgrave, 'Een maximalistische visie op herstelrecht', Tijdschrift voor Herstelrecht 2009 (3), p. 19-38., p. 20. 'tweevoudig geweld'). ${ }^{21}$ Anders zouden ook maatregelen die tegen de wil van de dader worden opgelegd, zoals tbs met dwangverpleging, als straf moeten worden gekwalificeerd - wat niet het geval is. Evenals bij straf c.q. vergelding ligt bij herstel de nadruk op het terugbrengen van de door misdaad verstoorde balans. Echter, herstel houdt niet in de dader met gelijke munt terugbetalen, maar hem de schade laten herstellen die hij heeft veroorzaakt $^{22}$ - idealiter 'vrijwillig', zo nodig dus met dwang. Herstel is een vorm van 'omgekeerde vergelding'. ${ }^{23}$ Anders gezegd: straf is vergelding van kwaad met kwaad, herstel is vergelding van kwaad met goed. ${ }^{24}$

\subsection{De taakstraf omgevormd tot 'herstelverplichting'}

Indien overeengekomen herstel middels 'vrijwillige overlegprocessen' onmogelijk blijkt, dan komt in een maximalistisch herstelrecht door de officier van justitie dan wel de rechter opgelegd herstel in beeld. Hierbij dient primair te worden gedacht aan de verplichting tot schadevergoeding aan het slachtoffer en de verplichting tot het verrichten van onbetaalde herstelwerkzaamheden jegens het slachtoffer en/of de gemeenschap. ${ }^{25}$ Het huidige sanctiearsenaal overziend kan worden gesproken van de oplegging van een schadevergoedingsmaatregel (art. 36f Sr) en een taakstraf (art. 22c Sr). Om de taakstraf werkelijk vorm te geven als een herstelverplichting is het noodzakelijk om het reparatoire karakter ervan te vergroten en het vergeldende karakter ervan te verkleinen. Dat kan door bij de bepaling van de inhoud van de onbetaalde herstelwerkzaamheden aansluiting te zoeken bij de gepleegde misdaad en/of het slachtoffer en/of de getroffen gemeenschap. ${ }^{26}$ McCold \& Wachtel spreken in dit verband van een related community service als deels herstelgerichte sanctie; ${ }^{27}$ men zou ook kunnen spreken van een 'herstelgerichte taakstraf', al verdient de term straf in het herstelrecht niet de voorkeur wegens de link met vergelding. Ter omvorming van de taakstraf tot een herstelverplichting dient er tevens naar te worden gestreefd om de conflictpartijen zo veel mogelijk zelf de inhoud van de herstelwerkzaamheden te laten bepalen via mediation dan wel een herstelconferentie. ${ }^{28}$

\subsection{De elektronische detentie omgevormd tot 'huis van herstel'}

In een maximalistisch herstelrecht is voor vrijheidsbeneming uitsluitend plaats indien de dader een onverantwoord gevaar vormt voor de openbare veiligheid - ter

21. Claessen 2020, p. 21-22.

22. H. Zehr, The Little Book of Restorative Justice, New York: Good Books 2015, p. 75.

23. Walgrave 2009 p. 20; Claessen 2020, p. 22-23.

24. J. Claessen, Misdaad en straf, Nijmegen: Wolf Legal Publishers 2010, hoofdstuk 3.

25. Claessen 2020, p. 23.

26. J. Claessen, 'Sanctionering van verkeersongevallen. Op het kruispunt van taakstraffen, verkeersdelicten en herstelrecht', Tijdschrift voor Herstelrecht 2019 (3), p. 12-29.

27. P. McCold \& T. Wachtel, 'In Pursuit of Paradigm: A Theory of Restorative Justice', International Institute for Restorative Practices 2003, te raadplegen via: www.iirp.edu/pdf/paradigm.pdf.

28. Claessen 2020 , p. 24 
preventie dus. ${ }^{29}$ Deze vrijheidsbeneming dient niet enkel in het teken te staan van maatschappijbeveiliging door opsluiting, maar ook van resocialisatie door behandeling. In het kader van herstel wordt immers ook aandacht besteed aan de oorzaken die tot de misdaad hebben geleid. ${ }^{30}$ In feite krijgt de vrijheidsbeneming daarmee het karakter van een maatregel, zoals tbs met dwangverpleging van overheidswege. Als er geen sprake is van dadergevaarlijkheid die noopt tot vrijheidsbeneming én geen vrijwillig herstel mogelijk is, dan is door de officier van justitie dan wel de rechter opgelegd herstel de aangewezen sanctie, waarbij de 'herstelgerichte taakstraf' de eerstaangewezen sanctie is.

Wat nu te doen met thuisdetentie vanuit een maximalistisch herstelrechtelijk perspectief? Omdat herstelrecht niet enkel gericht is op het herstellen van aangerichte schade, maar tevens op het voorkomen van nieuwe schade (waarbij ook dient te worden gedacht aan detentieschade), vind ik dat thuisdetentie wel degelijk kan worden verdedigd vanuit een maximalistisch herstelrecht, met dien verstande dat zij zich as such lastiger laat verdedigen dan de taakstraf. Echter, net zoals de taakstraf kan worden omgevormd tot een herstelverplichting, zo kan elektronische detentie worden omgevormd tot een 'vrijplaats' oftewel 'huis van herstel', van waaruit de dader - met hulp en steun - kan werken aan herstel van zichzelf (denk hierbij aan scholing, werk, training en therapie) alsook jegens het slachtoffer en de gemeenschap (bijvoorbeeld in het kader van mediation of een herstelconferentie). Bij het 'huis van herstel' kan tevens worden gedacht aan meer bottom-up controle in de vorm van COSA-achtige projecten. ${ }^{31} \mathrm{Op}$ de vraag of thuisdetentie een vrijheidsbenemende of -beperkende sanctie is, wordt verschillend geantwoord. Wanneer het een aangeklede, op herstel en resocialisatie gerichte sanctie betreft, gaat het in mijn visie om een (vergaande) vrijheidsbeperkende sanctie - die alleszins de voorkeur verdient boven (kale) vrijheidsbeneming in de gevangenis vanuit vergeldingsoogpunt.

Tot slot dient te worden opgemerkt dat in de zwaarste gevallen kan worden gekozen voor een combinatie van herstelgerichte taakstraf en herstelgerichte thuisdetentie, zij het dat vanuit een maximalistisch herstelrechtelijk perspectief bezien de voorkeur uitgaat naar een zo groot mogelijke inzet van de herstelgerichte taakstraf zonder thuisdetentie.

\subsection{Vervangende taakstraf en vervangende thuisdetentie}

Momenteel geldt dat, indien een geldboete niet wordt betaald of een taakstraf niet wordt volbracht, de dader alsnog de gevangenis in moet (vervangende hechtenis).

29. Walgrave 2009, p. 35

30. Zehr 2015, p. 40.

31. COSA staat voor Cirkels voor Ondersteuning, Samenwerking en Aanspreekbaarheid. Dit intensieve begeleidingstraject wordt ingezet bij de re-integratie van zedendaders die onder toezicht staan van de reclassering. Zie voor meer informatie: www.reclassering.nl/over-dereclassering/wat-wij-doen/cosa.
Bezien vanuit een maximalistisch herstelrechtelijk perspectief, waarin opsluiting enkel gerechtvaardigd is vanuit preventieoogpunt, dienen alternatieven te worden ontwikkeld voor vervangende hechtenis. Daarbij kan worden gedacht aan een vervangende taakstraf bij een niet betaalde boete en aan vervangende thuisdetentie bij een niet volbrachte taakstraf. Anno 1886, toen ons huidige Wetboek van Strafrecht in werking trad, bestonden, zoals gezegd, slechts twee hoofdstraffen: de geldboete en de vrijheidsbenemende straf. Indien een geldboete niet werd betaald, restte niets anders dan de opsluiting van de dader. Nu sinds 2001 de taakstraf een zelfstandige hoofdstraf is, vind ik het opmerkelijk dat nooit is nagedacht over de invoering van de taakstraf als vervangende sanctie in geval van niet-betaling van een geldboete. ${ }^{32}$ En nu in deze bijdrage tevens wordt gepleit voor de invoering van thuisdetentie, ligt een gelijktijdige invoering van vervangende thuisdetentie bij niet-volbrenging van een taakstraf eveneens voor de hand. Vanzelfsprekend zullen deze vervangende sancties niet in alle gevallen uitkomst kunnen bieden, maar ze verdienen in beginsel wel de voorkeur - mede bezien vanuit een maximalistisch herstelrechtelijk perspectief.

\subsection{Subsidiariteitsbeginsel}

Het subsidiariteitsbeginsel houdt in dat (straf)recht het laatste redmiddel hoort te zijn, omdat straf c.q. intentionele leedtoevoeging uitsluitend mag worden toegepast indien dat echt noodzakelijk is. Terwijl externe subsidiariteit ziet op het zo min mogelijk criminaliseren van ongewenst gedrag en het zo veel mogelijk voorkomen van dergelijk gedrag langs andere wegen dan het strafrecht, ziet interne subsidiariteit op het zo min mogelijk toepassen van dwangmiddelen tijdens het strafproces en het zo min mogelijk opleggen van straf in het kader van de sanctionering. ${ }^{33}$ Terwijl herstelrechtvoorzieningen buiten het strafrecht (bijvoorbeeld buurt- en herstelbemiddeling) een operationalisering vormen van de externe subsidiariteit, dragen herstelrechtvoorzieningen en herstelgerichte sancties in het strafrecht (waaronder mediation en de herstelconferentie respectievelijk de herstelgerichte taakstraf en herstelgerichte thuisdetentie) bij aan de operationalisering van de interne subsidiariteit. In onderstaande piramide wordt deze interne subsidiariteit tot uitdrukking gebracht, doordat daarin in het kader van de sanctiedoelen, sancties en sanctionerende instanties de volgende rangorde is aangebracht: van 'geen dwang' (consensueel herstel) in de basis via 'enkelvoudige dwang' (opgelegd herstel en maatregelen) naar 'tweevoudige dwang' (intentionele leedtoevoeging) in de top. ${ }^{34}$

32. Zie in dit verband het recente pleidooi van Johan Bac: Reclassering pleit voor vervangende werkstraf in plaats van korte celstraf, https:// www.reclassering.nl/actueel/nieuws/reclassering-pleit-voorvervangende-werkstraf-in-plaats-van-korte-celstraf.

33. J. Blad, 'Herstelrecht en subsidiariteit van strafrecht. Een pleidooi voor herstelrecht als operationalisering van subsidiariteit', Tijdschrift voor Herstelrecht 2015 (2), p. 14-29, p. 22.

34. Zie voor de basisidee waarop deze piramide is gefundeerd (namelijk het onderscheid tussen 'geen dwang', 'enkelvoudige dwang' en 'tweevoudige dwang'): J. Claessen, 'Pleidooi voor een ruimer strafbegrip of een 


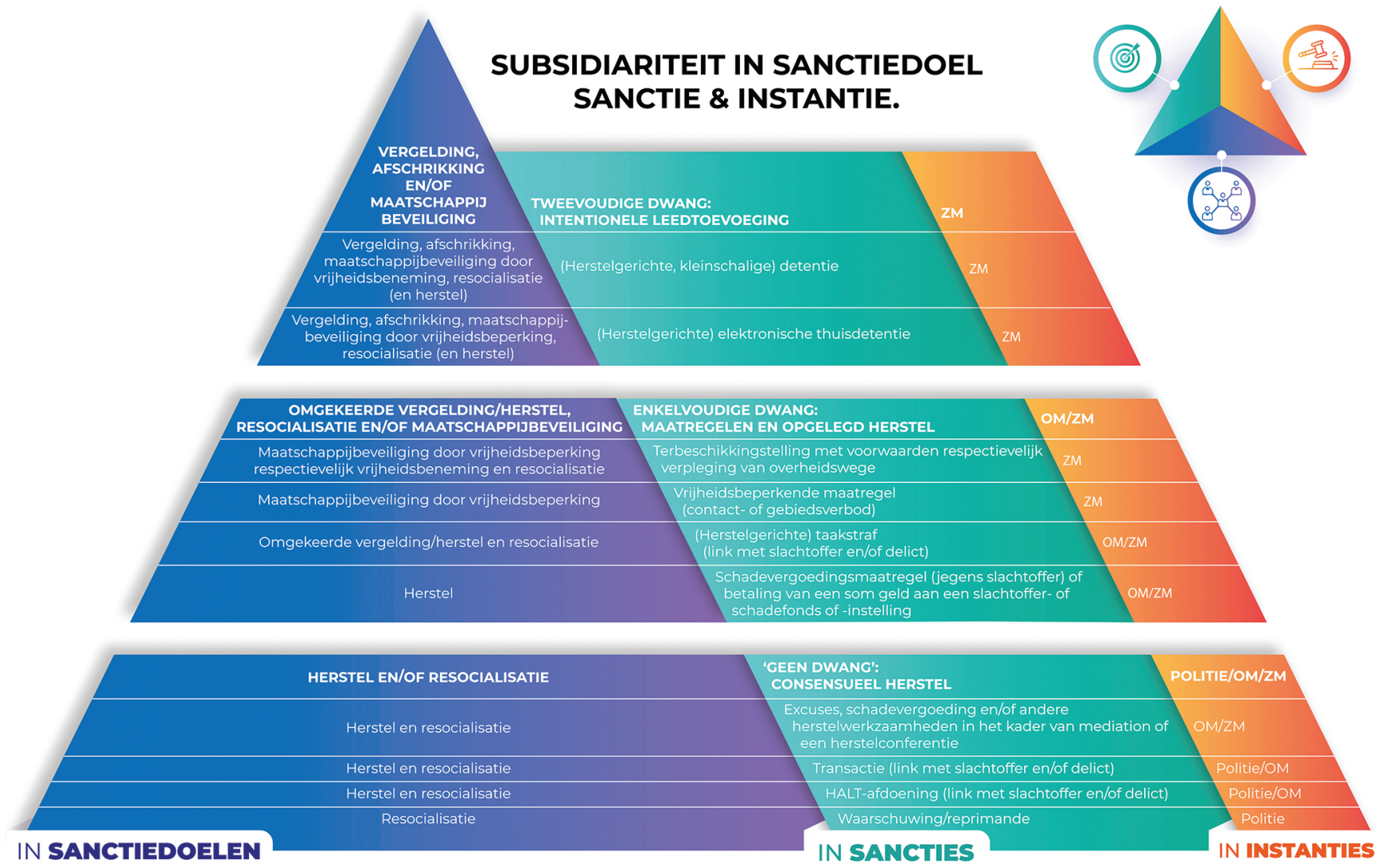

In een maximalistisch herstelrecht ligt de focus op sancties waarbij sprake is van 'geen dwang' en 'enkelvoudige dwang', - en wel in die volgorde. Sancties waarbij sprake is van dubbele dwang kunnen in beginsel vanuit een maximalistisch herstelrechtelijk perspectief niet worden gerechtvaardigd, daar zij overduidelijk leedtoevoeging beogen. Alleen door deze sancties om te vormen tot herstelgerichte interventies - en daarmee het reparatoire karakter van deze sancties te vergroten en het vergeldende karakter ervan te verkleinen - kunnen zij tot op zekere hoogte legitiem worden gemaakt. Voor herstelgerichte detentie is dit overigens lastiger te realiseren dan voor herstelgerichte thuisdetentie, aangezien de vrijheidsbeneming waarmee de gevangenisstraf gepaard gaat een vorm van vergelding blijft die herstel en resocialisatie bemoeilijkt.

\section{Straftoemetingsregels}

Deze bijdrage kan worden beschouwd als een pleidooi voor een ruimere toepassing van de taakstraf, de omvorming van de taakstraf in herstelrechtelijke richting en de invoering van thuisdetentie in herstelgerichte vorm - dit om de toepassing van de korte gevangenisstraf terug te dringen. Stel dat deze uitbreiding van het sanctiepalet zou slagen, dan kan de rechter vervolgens volledige straftoemetingsvrijheid worden gegeven - zoals hij graag wil. Om de korte gevangenisstraf de facto terug te

strafrecht zonder straffixatie?', Tijdschrift voor Herstelrecht 2012 (4), p. 37-49. dringen zou dan vooral de nadruk moeten liggen op (verdere) voorlichting over de negatieve effecten van de korte gevangenisstraf en de positieve effecten van de hiervoor besproken alternatieven, alsook op (verdere) voorlichting over maximalistisch herstelrecht met zijn concepten als opgelegd herstel en omgekeerde vergelding. Voorts zou kunnen worden ingezet op een aanpak waarbij de rechter wordt gestimuleerd om 'doelbewust' te sanctioneren, i.e. om meer dan thans het geval is expliciet in zijn uitspraak aan te geven met welk(e) doel(en) voor ogen hij zijn keuze voor sanctiesoort, -modaliteit en -maat maakt. ${ }^{35}$

Het meest vergaand zou de invoering van straftoemetingsregels naar Duits voorbeeld zijn. In Duitsland treffen we in artikel 46 van het Strafgesetzbuch de regel aan dat een vrijheidsstraf onder de zes maanden 'slechts wordt opgelegd als bijzondere omstandigheden, gelegen in het feit of de persoonlijkheid van de dader, de oplegging van een vrijheidsstraf met het oog op beïvloeding van de dader of de bescherming van de rechtsorde noodzakelijk maken' (mijn cursivering, JC). ${ }^{36}$ Onze oosterburen hebben dus een straftoemetingsregel in het leven geroepen die expliciet ziet op terugdringing van de korte vrijheidsstraf. De oplegging ervan lijkt vrijwel uitsluitend mogelijk vanuit preventieoogpunt: indien speciale

35. H. Lensing, 'Een Algemeen Deel voor de oriëntatiepunten? Een paar opmerkingen vanuit het perspectief van enkele andere stelsels', Tijdschrift voor rechtspraak en straftoemeting 2018 (2), p. 15-27; P.M. Schuyt, 'Doelbewuste straftoemeting', Sancties 2011 (4), p. 223-231.

36. J.W. Fokkens, 'Oriëntatiepunten en verbetering van de straftoemeting', Tijdschrift voor rechtspraak en straftoemeting 2018 (2), p. 5-14, p. 11; Lensing 2018, p. 18. 
preventie (resocialisatie) en/of maatschappijbeveiliging (opsluiting) daartoe nopen. Een dergelijke regel klinkt mij als muziek in de oren, aangezien zij impliciet aanzet tot het zoeken naar alternatieven. Geinspireerd door het Duitse recht zou aan artikel $10 \mathrm{Sr}$ een vijfde lid kunnen worden toegevoegd, luidende: 'Een gevangenisstraf tot zes maanden wordt niet opgelegd, tenzij de resocialisatie van de verdachte dan wel de waarborging van de openbare veiligheid daartoe noopt en elektronische detentie daarin onvoldoende kan voorzien.' Wanneer thuisdetentie zou worden ingevoerd, zou in het Wetboek van Strafrecht een regel met de volgende strekking kunnen worden opgenomen: 'Thuisdetentie wordt enkel opgelegd in die gevallen, waarin de rechter een vrijheidsstraf had opgelegd wanneer thuisdetentie niet tot de mogelijkheden had behoord en waarin de resocialisatie van de verdachte dan wel de waarborging van de openbare veiligheid daartoe noopt.' Door een dergelijke regel kan een aanzuigende werking vanuit de taakstraf richting thuisdetentie worden voorkomen; indien kan worden volstaan met de oplegging van een taakstraf, dan heeft dat vanuit een maximalistisch herstelrechtelijk perspectief immers de voorkeur boven vergaande vrijheidsbeperking (thuisdetentie) of vrijheidsbeneming (de gevangenis). Door zulke regels op te nemen in het Wetboek van Strafrecht zou de wetgever bij minder ernstige criminaliteit een principiële keuze maken voor de volgende sanctievolgorde, waarbij ik gemakshalve de geldboete buiten beschouwing laat: 1 . taakstraf, 2 . thuisdetentie en 3. detentie. Voor (thuis)detentie is alleen plaats vanuit preventieoogpunt; vergelding wordt in de vorm van verplichte herstelwerkzaamheden gegoten.

\section{Uitleiding: de noodzaak van kleur bekennen}

Ik zeg altijd tegen mijn studenten: uiteindelijk zul je een keuze moeten maken: kies je voor vergelding en dus voor de bevrediging van wrakkzucht op korte termijn of voor resocialisatie en dus voor het voorkomen van nieuwe slachtoffers op langere termijn? Kies je voor streng straffen of voor slim straffen? Kies je voor het toebrengen van nog meer schade óf voor het herstellen en voorkomen van schade? Beide blijken nu eenmaal niet goed samen te gaan - alle verenigingsdenken ten spijt. ${ }^{37}$ Je kunt niet de kool en de geit sparen - al probeert de politiek ons dat steevast wijs te maken. ${ }^{38}$ Zeker bij minder ernstige criminaliteit zou ik ervoor willen pleiten om hartgrondig en vol overtuiging te kiezen voor

37. Claessen 2010, hoofdstuk 4

38. Zie in dit verband onder meer S. Dekker, Recht doen, kansen bieden. Naar effectievere gevangenisstraffen, d.d. 17 juni 2018 (visiedocument) en het (hierop gebaseerde) Voorstel van wet tot wijziging van de Penitentiaire beginselenwet, het Wetboek van Strafrecht en enige andere wetten in verband met de wijziging van de regelingen inzake detentiefasering en voorwaardelijke invrijheidstelling (Wet straffen en beschermen die 1 juli 2021 in werking is getreden, Kamerstukken II, 35122). slim straffen, en wel door de invoering en toepassing van alternatieven voor de korte gevangenisstraf. Zo blijken de taakstraf en thuisdetentie effectiever in termen van recidivereductie, terwijl zij tevens - zij het op meer humane, constructieve wijze - kunnen voorzien in de behoefte aan genoegdoening, zeker wanneer deze alternatieven op herstelgerichte leest worden geschoeid. Bovendien zijn ze goedkoper.

De vraag is hoe we voldoende draagvlak kunnen creëren voor deze ideeën, gezien het huidige punitieve klimaat in de politiek. De wetenschap biedt hiervoor aanknopingspunten. Zo blijkt onder meer dat de taakstraf over het algemeen mag rekenen op brede steun in de samenleving en dat die steun kan worden vergroot door mensen meer informatie te geven over de positieve effecten ervan. ${ }^{39}$ Waarom zou dat bij (een aangeklede, herstelgerichte vorm van) thuisdetentie anders zijn? Tevens blijkt uit onderzoek dat meer informatie over een concrete strafzaak en begrijpelijkere uitspraken van rechters bijdragen aan verkleining van de zogeheten punitiviteitskloof. ${ }^{40}$ De vraag is uiteindelijk of de politiek en de media klaar zijn om de waarheid te spreken als het gaat om een misdaadaanpak die echt werkt.

39. S. Ruiter, J. Tolsma, M. de Hoon, H. Elffers \& P. van der Laan, De burger als rechter. Een onderzoek naar geprefereerde sancties in Nederland, Den Haag: Boom Lemma 2011.

40. M. van der Maden, M. Malsch \& J. de Keijser, 'Waarom wil de burger toch steeds dat rechters zwaarder straffen? De invloed van opleiding en informatie', Trema 2017, p. 180-183. De punitiviteitskloof houdt - kort gezegd - in de kloof tussen de daadwerkelijke sanctionering door de rechter en de door de burger gewenste sanctionering. 